\title{
Re-reading the Country: A Settler Genealogy of Place
}

\section{Kate Leah Rendell}

'Oh'-

'Hello'

'Hello', we say-

'Where you come from?'

Paddy Roe ${ }^{1}$

'Isn't it a very basic and important thing to know, from someone's tracks, where they have come from and which way they are going?'

Stephen Muecke ${ }^{2}$

Last year my father and I made a trip north to the farmlands adjacent to the Murray River in north-central Victoria.

Travelling through the communities of Barmah, Picola and Nathalia, we mapped our family's tracks of 'settlement' and 'selection'. It was simultaneously a journey of return and first encounters - an attempt to retrace our genealogy of place and, for me at least, to interrogate the implications of our history. ${ }^{3}$ The desire to undertake this tracking had emerged from the intersections of recent work: a project on the Settler author Randolph Stow, particularly my thinking around his exile to England as a response to his 'unbelonging' in Australia; discussions within the Australian Indigenous Studies program at the University of Melbourne; a foray into Tony Birch's seminar Genealogy of Place; and of course the work of Paddy Roe, Stephen Muecke and Krim Benterrak in their seminal book Reading the Country. Across these various threads a key question kept emerging - what of Settler connection to country? What of my connection? Central to this was Paddy Roe's 
evocation: 'You people try and dig little bit more deeply-you bin digging only white soil - try and find the black soil inside.' ${ }^{4}$

In this chapter I take Roe's appeal not as an invitation to simply borrow from Aboriginal readings of country, but rather for Settler Australians to dig more deeply and interrogate more fully our own narratives of place in relation to Aboriginal sovereignty. I suggest that if we are to take heed of the generosity of Roe's philosophy, Settler Australians need to question our comfortable narratives of arrival, settlement and homemaking, which continue to evade the historical and contemporary colonising project. It is an interrogation that presents opportunities for new readings of country, grounded in an awareness of Settler presence as inherently possessive. ${ }^{5}$ Or, as Aileen Moreton-Robinson writes: 'what requires further theorizing is how the white and non-white postcolonial subject is positioned in relation to the original owners not through migrancy but possession'.6 In my own case this requires an unravelling of familiar/familial narratives of 'settlement' that have circulated my whole life implicitly connecting me to a place that I have never actually lived in and marking me with an agricultural/rural identity that I have never actually inhabited. It is an interrogation that starts at 'home'.

I embark on this journey with my father, Rob. Not only is he strongly connected to the rural tracks I seek to follow, he is also an enthusiastic and knowledgeable companion, keen to share this story with me. A fourth-generation Anglo-Celtic Australian, my father grew up on a mixed sunflower/sheep/ wheat irrigation farm in the Murray-Goulburn region and honed this experience into a long and successful career in agricultural consulting. Somewhat of an expert on irrigation, salinity and agriculture, Rob jumped at the opportunity to show me around the farmlands of our family - to offer his reading of country informed by a career mapping, testing and surveying the land.

Following the tracks of my paternal line we drive first to 'Longfield Farm', a parcel of land at the edge of the Barmah Forest on the Victorian side of the Murray River, between Picola, Yielima and Yalca South on Yorta Yorta country. Longfield is the original Rendell 'selection', 'taken up' in 1876. Although not the farm my father and grandfather grew up on, 
Longfield is still farmed by a Rendell and continues to mark and name our history of place.

We are greeted at Longfield by a distant third cousin of mine, who is most obliging of our request to see the farm, if not a little reticent (no doubt wondering what exactly it was this young woman from the city wanted to know). We are shown the original paddocks, the old dairy, remnants of the first buildings, and the rusty gate declaring this property to be 'Longfield Farm'. While walking across one of the paddocks, the Rendell farmer reflects on his desire to see the land as it had been: 'wouldn't you love to see it before it was cleared'. We had just been talking of the effort required to clear the land 'all by hand', and I got the sense that his comment did not express a desire to bear witness to Yorta Yorta land management practices, or register the full extent of dispossession enacted in the clearing-but rather expressed a yearning to relive the struggle, to revisit the hard work of his forebears. There was pride and wonder in his tone. Yet I could not help but look over at the protected forest of Barmah and think of what was felled, of the canoe trees, hunting grounds and gathering places that once proliferated on this property, the other narratives worthy of pride and wonder in this land.

This was the first journey I had ever made to the original Rendell farm. Despite it playing a significant part in my genealogy of place, I had never considered its story relevant to my contemporary urban identity and certainly hadn't sought out the history of its 'selection'. This kind of genealogical ahistoricism is a powerful phenomenon within Settler Australia, especially for young third, fourth and fifth generation white Settlers. It's an ahistoricism that became particularly evident to me within Indigenous Studies tutorials at the University of Melbourne, where in the interests of working towards safe and open discussion I would ask students to introduce themselves with reference to their identity and positionality. White Settler Australians struggle with this request to position ourselves - 'I am Australian', we say, or 'I suppose I am AngloSaxon'-with little reference to specific heritage or place. What became clear is that very few white Settlers could answer the genealogical questioning that our nation-state demands with any identification of Aboriginality. We could not map the 
familial lines. We are not asked to. In fact, in the interests of the national Australian narrative we are required not to know, or to know only certain versions. This is not a passive unknowing, but a complacency made possible by the imperatives of colonialism, 'terra nullius' and the forging of new 'Australian' identities. Re-reading country as Settler therefore means being prepared to inhabit the colonial implications of your presence and the histories your lineage carries. It includes a responsibility to track these histories and unravel the mythologies that surround them.

For me, it is about coming to terms with Settler genealogies of place as an enactment of dispossession. In my case this genealogy is particularly agrarian: white settlement established through farming. It is a remarkably uniform heritage: all sixteen of my great-great-grandparents arrived from England, Scotland and Ireland around the 1850 s and all eight families 'took up', 'acquired' or 'selected' properties across Victoria during the land grab made possible by the Land Act of $1869 .{ }^{7}$ This was the Act that parcelled out the last remaining tracts of uncleared land across Victoria. Divided into 320 acre 'allotments', as Paul Carter writes, 'selections were offered indiscriminately to individual owners - with the result that, instead of creating a network of public and private spaces, the Land Act simply encouraged a proliferation of clearings'. ${ }^{8}$ With the Act requiring that all 'selections' be fenced and cleared within two years of possession, 'selectors' set to work razing the land with little regard for Aboriginal occupation. At $£ 1$ an acre, these allotments presented to my ancestors, many of whom had been poor tenant farmers in England, a golden ticket to property ownership. In particular, for Andom Rendell, a convict transported for arson and the first Rendell in Australia, the Land Act presented an unimaginable opportunity for reinvention. ${ }^{9}$ For Aboriginal people across Victoria, however, the Land Act and subsequent 'selections' represented a method of terrible and irrevocable dispossession, as people were forced off the last remaining pockets of uncleared country into missions and reserves.

To uncover our own role in this history of 'selection' and dispossession, my father and I trace our familial lines. We draw directly onto a map of Victoria; encircling properties 
in Yorta Yorta, DjaDjaWurrung and Taungerang country, we track my ancestors' possession of land in Yielima, Waaia, Carisbrook and Gerang Gerung. My father seems genuinely to enjoy this tracing, mapping the generations of farming that have shaped him. It is the similarity, the consistency, of the farming story - the agrarian lineage - that animates him. It is the very same aspect of the story that unsettles me.

It is not an easy thing to interrogate our family's history in this way. Katrina Schlunke suggests that 'these intimate histories somehow take you aside, very personally, into your family, your place' and asks: 'Is there something vaguely sinister about it?'10 Walking the paddocks of Longfield certainly did feel somewhat sinister-even conspiratorial. As did asking questions of my family, querying their knowledge of Aboriginal sovereignty and their sense of complicity in Yorta Yorta dispossession. When I think of those in my extended family who have not read or heard me speak of this project, it still does.

Tracking our genealogy of place in relation to Aboriginal sovereignty and dispossession is an interrogation of history and identity that has implications for both my father and me, but more explicitly for him. My questions are a direct challenge to his proud farming background. Reflecting an identity woven into place and drawn from a real affinity to the land, Rob writes in an email:

Despite a totally different concept [to Aboriginal people] I certainly had an affinity with the country, the moon at nights while walking around the paddocks irrigatingsome of the trees particularly the yellow box, the sheoaks and the Murray pine ... I think the summer nights were the best ... the experience of seasons and the dust and the wet and the spring is something that I don't get the same now.

Yet, he stalls when I suggest that his own affinity to the land is completely reliant on the erasure of Aboriginal presence, history and sovereignty. I have put him on the spot. Who am I to criticise? As Muecke writes, 'we are all spinners of texts'11 and as my father would say, I too am in this 'up to my neck'. Nevertheless, my father considers my questions, grapples with the implications. 
In one email, sent after reading an early draft of this chapter, my father concedes that Aboriginal sovereignty was never at the forefront of his ancestors' minds: 'I suppose to be honest it was also about control and production ... the 50,000 years of the Indigenous was a foreign concept'. In the same email he writes: 'Couldn't sleep for thinking of the story ... asking the question why does the settler story totally exclude the Indigenous history.' I want to explain to him that our micro-history does not exist in isolation, that our narrative relates to the wider colonial project. I want to say that this love of the land is precisely why it's so difficult for many Settler Australians to acknowledge Aboriginal dispossession. And I do. But it seems such a personal attack. As North American scholars Eve Tuck and K. Wayne Wang write, 'directly and indirectly benefitting from the erasure and assimilation of Indigenous peoples is a difficult reality for settlers to accept'.12

So we start at Longfield Farm - because this farm, as the first Rendell property, represents the strongest symbol in our familial lines of possession. We seek out the narratives of this place and look for the gaps, the silences and the erasures. I am lucky that my father joins me.

\section{Yeilima: 'Longfield Farm'}

The histories of Longfield we uncover project a sanitised, even flippant narrative of 'settlement'. In almost all cases the historical depictions downplay the nuances and complexities of 'settlement' (including the role of women, class hierarchies between convicts and 'free settlers', religious divisions-in our family's case between the Protestants and Methodists), but most perversely they reveal a complete disregard for Aboriginal sovereignty. In the auspiciously titled Pioneers of Nathalia $\mathcal{E}$ District, pre 1900: A History of Fifty-Seven Families, who Resided in the Nathalia Area before 1900, written by the 'Genealogical Society of Nathalia' in 1985 and a permanent fixture of my family's bookshelf, the Rendell 'selection' of Longfield is inscribed in the most banal terms: 'when Yeilima was thrown open for selection ... Walter selected 320 acres, being allot.54 for himself and allot.53 for his father Andom also being 320 acres'.$^{13}$

By all accounts Andom and Walter's 'selection' of Longfield was a successful one. Profiled in the local newspaper, the 
Nathalia Herald, in 1887, 'the property of Mr. Andom Rendell' is described as award-winning: 'Mr Rendell's farm took the second prize in the farming competition ... It is not often that a farm so far out is so far advanced. ${ }^{14}$ Written eleven years after the original 'selection', the profile piece focuses on the 'well-ordered' state of the farm and the strong work ethic of the Rendell farmers:

The place gives one the impression of well-ordered plenty and content; the plenty was not conducive to sloth, as the tidiness of the place showed; nor the content to idleness, for the hum of the winnower and the thresher was heard on the land as we arrived. ${ }^{15}$

Poetic references to toil, cultivation and productivity abound in the description. It is a depiction of farming that reinforces the Lockean principle of labour as value, so central to the western-imperial concept of property ownership and the colonising project in Australia. In many ways I had anticipated this expression of production, yet I had also assumed this representation would rely on the total silencing of Yorta Yorta history. It was surprising therefore to read references to Aboriginal presence in the profile of Longfield Farm in 1887:

Half a mile across the road Mr Rendell has another property boarding the inundation of the Murray. On this which is ringbarked, but not yet cleared, some dairy cattle are kept. Kangaroos are not rare, and the trees bear many traces of the black fellows, where they have notched the trunk to climb the trees, and here and there openings have been cut in the trunks. ${ }^{16}$

I text my father to ask what tools exactly Andom and Walter would have used to clear the new paddocks, now part of an expanding Rendell property domain - how was it done? The text comes back abrupt and matter of fact: 'Axe to ringbark the tree to kill them - then cross cut saw with two people to drop the tree - then burn the stumps and wood.' It seemed so final; so violent. I think of the trees slowly dying then so wastefully burnt on site. I think of 'the many traces of the blackfellows' that were felled in the process. 
In tracing the history of 'Longfield Farm', my research reveals that the farm is within the country of the Bangerang clan of the Yorta Yorta people. When I mention this to my father, he responds that he knew of Bangerang - in fact his high-school magazine was called that. There is a cruel irony in the recognition. I think of Bruce Pascoe's reference to the Settlers compulsion to name properties in Aboriginal language:

To remember the original name even while trying to forget how the property came under white ownership. As if usurpation is not complete unless you steal the name as well. It's eerie to have the name but none of the people. ${ }^{17}$

Of course, Bangerang people were not completely absent at the time of the first Rendell possession (or indeed when my father was at high school), though the early waves of colonisation had severely diminished their population. As Yorta Yorta Elder Wayne Atkinson records, precolonisation figures suggest a population of 2500 to 3000 Yorta Yorta people, yet this population:

was reduced by $85 \%$ in the first generation of white contact and it did not stop there. The Victorian Aborigines Protection Board estimated that in the Victorian section of the [Yorta Yorta Native Title] claim area (1863) there were only 365 Yorta Yorta survivors. ${ }^{18}$

In 1876, around the time of Rendell possession of Longfield, Atkinson writes that surviving Yorta Yorta people were mostly living in camps on the fringes of pastoral stations, supporting themselves by hunting and fishing. ${ }^{19}$ Self-subsistence was supplemented by a necessary contact with the local stations and reserves:

Ration depots were located on pastoral stations ... Some land was also reserved for Yorta Yorta use at Whugunya (near Corowa) ... From 1861-91, these became important bases for the Yorta Yorta to seek aid and to maintain connections with country. ${ }^{20}$ 
One such reserve was 'Maloga Mission', established as a school and mission station near Echuca in 1874 by Daniel Matthews. Research into this mission conducted by the Federal Court during the Yorta Yorta Native Title Claim suggests that residence at Maloga in the early years:

tended to be intermittent. Most of those at Maloga were from Moira, and moved between the mission, a camp at Moira Station and camps around the Moira Lakes and Barmah Forest. ${ }^{21}$

The Federal Court research further revealed, however, that numbers at the mission 'increased steadily during 1877 ' and peaked 'in 1886 '. ${ }^{22}$ Reading such findings I am struck by the very direct correlation between the population increase at Maloga Mission in 1877 and the establishment of 'Longfield Farm' in 1876. Such effects seem so obvious now, given the widespread dispossession enacted by the Land Act 'selections'-but Maloga Mission and the stories of Yorta Yorta people being forced off their land into residence there are completely absent from my family's founding narratives. Similarly, the salient correlation between the Victorian Aborigines Protection Act of 1869 (which gave the government unprecedented discretionary power to relocate Aboriginal people and remove children) and the Land Act of 1869- two parliamentary acts which directly facilitated my family's possession of Yorta Yorta land-are palpable omissions from our stories of successful 'settlement'.

\section{Picola: memorialising settlement}

Seeking out the wider historical narratives publicly available to visitors on our journey through the Goulburn-Murray region, my father and I make a stop at the 'Historical Walk' in Picola. Picola is not the closest town to 'Longfield Farm', but it is nearby, and I had read that the town had recently commissioned a historical park. I was interested in the 'history' that Picola chose to tell. A one-street country town, total population 300, Picola consists of the park, the pub (which also operates as post office, milk bar and VLine ticket office) and the public hall. The park is simple: a small block of freshly 
mown grass, a rose garden, a barbeque hut and the public toilets. Along either side of the central walkway to the toilets is the recently installed signed walk: 'A Salute to Our Pioneers'.

Walking around the park, following the loop of signs, I can't help but wonder who actually stops here: who is the audience? No other cars pass while we are there, though the VLine bus does make its obligatory stop despite there being no passengers. Given you have to walk past the signs to reach the toilets, there is a chance a few passers-by might stop off, yet I am more inclined to suggest the park was established to reaffirm the local 'selector' community, rather than as a tourist attraction. It provides a visual guarantee that, despite the town's diminishing population, Picola's 'pioneering' history is not forgotten. Either way, for tourist or local, the historicising function of the walk is explicit in its aim to proclaim and 'salute' the 'improvements' brought by 'settlement'. As the final sign on the walk depicts it:

Reports of excellent pastures brought squatters from other areas to claim choice land ... By mid-1840s the first large runs such as Upper Moira, Lower Moira, and Yielima were established with stock grazing in the forest. The squatters' occupation was legalised in 1847.

In Victoria, public opposition to the squatter's occupation over Crown Lands led to legislation, culminating in the 1869 Lands Act, which broke up the large pastoral runs. In the early 1870 selectors began moving to this area to take up land ... and make improvements such as fencing, clearing and cultivation. ${ }^{23}$

According to a report in the Riverine Herald, this walk was completed in late 2014 and its construction was initiated and designed by the 'Picola and District Improvement Group'. The group's president, Jeanette Holland, claimed the walk was created in the interest of posterity: 'we didn't want the town's history to be lost'. ${ }^{24}$ Perhaps not surprisingly, therefore, the history the Picola and District Improvement Group choose to remember is a sanitised and selective narrative of 'our pioneers'. Visitors are not told that the 'choice land' was already 
occupied or that the establishment of this town dispossessed the Bangerang clan of the Yorta Yorta. We are told nothing about the mass displacement brought about by 'settlement' and 'selection'. Nor are we told of the irrevocable environmental violence that 'improvements such as fencing, clearing and cultivation' enacted on Yorta Yorta lands and waterways. Instead, historical narratives such as the Picola Historical Walk perpetuate the ongoing fallacy of Settler innocence; so, as Tony Birch writes, 'the pioneer success story that underpins the construction of the nation-state is able to present itself as the innocent agent of a struggle over adversity'. ${ }^{25}$ As Tuck and Yang reveal, such claims are the prerogative of the colonial project: 'for the settlers to make a place their home, they must destroy and disappear the Indigenous peoples that live there'. ${ }^{26}$ The signed walk of Picola does offer this acknowledgement: 'We respect the Aboriginal people who roamed on this land prior to settlement.' It is a strange offering that both recognises and disavows Aboriginal presence - with 'roaming' Aboriginal people represented as the disappeared while the contemporary and ongoing sovereignty of Yorta Yorta people is denied.

Yet there was a moment of slippage in the sanitised mythology of 'settlement' as presented by the historical walk. Standing in the Picola heritage park I could not help but notice the large Aboriginal flag flying high within the property on the opposite side of the street. The disjunct between the Aboriginal flag, a contemporary symbol of survival and sovereignty, and the past tense used by the historical society in reference to the Aboriginal peoples 'who roamed on this land prior to settlement' is telling. I did not meet the owner of the flag or the car adorned with Aboriginal stickers in the carport (I would have liked to have known what they thought of the historical walk) - yet the symbolic resonance of the red, black and yellow was felt, sending a current of Aboriginal resistance through the 'salute' to 'our pioneers' of Picola.

On the final leg of our journey my father and I make a stop at the Nathalia Cemetery to visit the graves of Andom and Walter, as well as other family members buried there. It is here on Walter's grave in the Rendell family plot that we find a plaque that reads: 
The descendants of Walter Rendell and Margaret Flett commemorate the settling of this land

5 th June 1876

Lot 54

'LONGFIELD'

5 th June 2000

My immediate family had not been present at this 'commemoration', in that auspicious millennial year. My father could not remember why. Yet he did not seem adverse to the sentiment of the event. In fact, he seemed disappointed we had not made it. Standing in the cemetery we discussed how the feat of our ancestors is one worthy of commemorating, that it is their journey across the seas, their toil on the land that we continue to benefit from. Yet I asked, and to continue to ask, what does it mean if this is the only version of the story we tell ourselves? Our story 'of settling this land' is a familiar and comfortable narrative in our family; it does not challenge our Settler 'innocence' nor does it speak to the profound dispossession we enact throughout our genealogy of place. If we seek to reread the country in relation to Aboriginal sovereignty and Settler possession, our story is far more complex.

In contrast to our story of 'settling this land', Ina Yillian is the Yorta Yorta creation story of Dungala [the Murray River] which tells of Biami the Creator Spirit, Gane the rainbow serpent and the old woman Gumuk Winga and her weary journey to find yams with her digging stick. It is a story in which Gane the rainbow serpent, following Gamuk Winga through country, creates deep tracks as his body moves across the land pushing the earth into hills and valleys, culminating in the creation of the river by the Creator Spirit:

Then Biami called out in a loud voice and thunder cracked as lightening flashed across the sky and rain fell ... Then the rain stopped and the mist cleared and the river Dungala was formed. This is the name used by the Yorta Yorta people. Others would know it as the Murray River. ${ }^{27}$

Published in the powerful collection Nyernila-Listen Continuously: Aboriginal Creation Stories of Victoria, this story 
is inscribed in Yorta Yorta language (spoken by Yorta Yorta clans including the Kaitheban, Wollithiga, Moira, Ulupna, Bangerang, Kwat Kwat, Yalaba Yalaba and Ngurai-illiamwurrung) and is translated into English by Djetcha Zeta Thompson. This story of Dungala, revealing the tracks of Gane engraved from time immemorial, expresses a sovereignty far stronger and infinitely deeper than the fresh tracks of my own family's 'settlement' and possession. Both tracks are there in the land-but Settler Australians must be more open and less defensive in order to read those deeper tracks, to 'try and find the black soil inside'. ${ }^{28}$

My father's own reading of country has altered in the process of this project: in a recent chapter he authored for the collection Decision-Making in Water Resources Policy, Planning and Management - The Australian Experience he writes: 'the history of agriculture and irrigation in northern Victoria is a story of farmers overcoming hardship and seizing opportunities. However, this was only possible at the expense of the indigenous Aboriginal inhabitants.' $29 \mathrm{He}$ acknowledges that his version tells the "post "selector" evolution of irrigation, because in reality, the Aboriginal peoples have been denied their rightful part.' 30 It is an unusual deviation, a side step from the statistics and 'objectivity' demanded in his line of work. He goes on to write:

this denial has continued even in the recent MurrayDarling Basin Plan (Aust Govt 2012), where although there have been many cultural surveys, consideration of the environment and agriculture is still primarily 'white fella' business. I hope we may combine the two stories one day, but at the moment the history is primarily about white people after the selectors. ${ }^{31}$

I am moved by the inclusion of these acknowledgements and I am glad that he's come with me on this journey. Rereading the country in relation to Aboriginal sovereignty and Settler possession is a project that my family are only just beginning; yet there is transformative potential in such rereadings, as my 95-year-old grandfather's response to this essay suggests: 
Kate, it is a very challenging article. Perhaps for the first time in my life I have been challenged as never before. I certainly was never made aware that we were living at the expense of a people who had lived where we were now living. And, without even a whisper that we were (there's a word I want to use - usurper and I don't even know to spell it.) I was blissfully unaware and this is a wake up call.

\section{John Rendell}

\section{Notes}

Krim Benterrak, Stephen Muecke and Paddy Roe, Reading the Country: Introduction to Nomadology, Fremantle Arts Centre Press, Fremantle, 1984, p. 129. Ibid. p. 210.

3 Throughout this essay I use the term Settler. In most cases I deploy this term in the broadest sense to refer to all non-Indigenous Australians living in Australia - as a differentiated identity from Aboriginal and Torres Strait Islander peoples. Settler in this instance includes all non-Indigenous people as implicated as beneficiaries of colonialism. However, Settler is also used refer to my specific heritage as the descendent of selectors - which is marked different from the experiences of recently arrived or non-white Settlers whose relation to settler colonialism is distinct. Where possible I have used Settler as the general term and white Settler/ selectors as specific to my personal identity.

4 Benterrak, Muecke and Roe, p. 194.

5 This is by no means a new proposition, there is much recent work that similarly calls for an acknowledgement of Settler identity as possessive and our presence as one of occupier, for example: Aileen Moreton-Robinson The White Possessive: Property, Power and Indigenous Sovereignty, University of Minnesota Press, Minneapolis, 2015; Toula Nicolacpoulos and George Vassilacopoulas, Indigenous Sovereignty and the Being of the Occupier: Manifesto for a White Australian Philosophy of Origins, Re.press, Melbourne, 2014; Tracey Banivanua Mar, 'SettlerColonial Landscapes and Narratives of Possession', Arena Journal, vol. 37 no. 38, 2012, pp. 176-98.

6 Aileen Moreton-Robinson, 'I Still Call Australia Home: Indigenous Belonging and Place in a White Postcolonising Society', in Uprootings/Regroundings: Questions of Home and Migration, ed. Sara Ahmed, Claudia Castañeda, AnneMarie Fortier and Mimi Sheller, Berg, Oxford, 2003, p. 36.

7 Paul Carter, The Road to Botany Bay: An Exploration in Landscape and History, University of Minnesota Press, Minneapolis, 2007.

8 Ibid., p. 169.

9 The convict status of Andom Rendell was concealed in our family for many generations - with my grandfather only finding out quite recently that Andom was transported for arson. It seems Andom's reinvention as a free selector presented a more favourable version of family history - such omission is a telling example of the silences and gaps in family histories.

10 Katrina Schlunke, Bluff Rock: Autobiography of a Massacre, Fremantle Arts Centre Press, Fremantle, 2005, p. 44. 
11 Benterrak, Muecke and Roe, p. 118.

12 Eve Tuck and K. Wayne Yang, 'Decolonization is Not a Metaphor', Decolonization: Indigeneity, Education E Society, vol. 1, no. 1, 2012, p. 9.

13 Genealogical Society of Victoria, Pioneers of Nathalia \& District, pre 1900: A History of Fifty-Seven Families, who Resided in the Nathalia Area before 1900, Nathalia Genealogical Group Inc., Nathalia, Vic., 1985, p. 62.

14 Ibid.

15 "Longfield" in the Parish of Yeilima, the Property of Mr. Andom Rendell', Nathalia Herald, 10 February 1887.

16 Ibid.

17 Bruce Pascoe, Convincing Ground, Aboriginal Studies Press, Canberra, 2007, p. 73.

18 Wayne Atkinson. 'Yorta Yorta Survival' in 'Not One Iota: The Yorta Yorta Struggle for Land Justice', PhD Thesis, LaTrobe University, 2000, p. 3. <https://waynera. files.wordpress.com/2010/10/yortasurvival.pdf>

19 Ibid. p. 8.

20 Ibid.

21 Federal Court of Australia, Members of the Yorta Yorta Aboriginal Community v Victoria \& Ors, FCA 1606, 18 December 1998.

22 Ibid.

23 Picola 'Heritage Walk'.

24 'Signs of Improvement at Picola', Riverine Herald, 13 December 2014.

25 Tony Birch, "'Death is Forgotten in Victory”: Colonial Landscapes and Narratives of Emptiness', in Object Lessons: Archaeology and Heritage in Australia, ed. Jane Lydon and Tracy Ireland, Australian Scholarly Publishing, Melbourne, 2005, p. 187.

26 Tuck and Yang, p. 6.

27 'Ina Yillian', Nyernila Listen Continuously, Arts Victoria, Melbourne, 2014, p. 53.

28 Benterrak, Muecke and Roe, p. 194.

29 Rob Rendell, 'Agriculture in Northern Victoria (Australia) over the Past 20-30 Years-Factors Influencing Decision-making by Individual Farmers', DecisionMaking in Water Resources Policy, Planning and Management - The Australian Experience, ed. Barry Hart and Jane Doolan, Elsevier: Academic Press, London, 2017, p. 62.

30 Ibid.

31 Ibid. 